\title{
Effects of dose of LH on androgen production and luteinization of ovine theca cells cultured in a serum-free system
}

\author{
B. K. Campbell ${ }^{1}$, D. T. Baird ${ }^{1}$ and R. Webb ${ }^{2 *}$ \\ ${ }^{1}$ Department of Obstetrics and Gynaecology, University of Edinburgh, Centre for Reproductive Biology, \\ 37 Chalmers St, Edinburgh, EH3 9EW; and ${ }^{2}$ Roslin Institute (Edinburgh), Roslin, Midlothian, EH25 9PS, \\ UK
}

The study reports the development of a serum-free culture system for sheep thecal cells that overcomes the problem of spontaneous luteinization and the use of this system to study the control of proliferation and differentiation. Theca cells were isolated by enzymatic dispersion from small follicles $(<3.5 \mathrm{~mm})$ and the effect of plating densities $\left(25-100 \times 10^{3}\right.$ cells per well), LH $\left(0.001-100 \mu \mathrm{g} \mathrm{I}^{-1}\right)$, insulin $\left(1-5000 \mu \mathrm{g} \mathrm{I}^{-1}\right)$, insulin-like growth factor I (IGF-I) analogue (1-100 $\mu \mathrm{g}$ LR3-IGF-I I ${ }^{-1}$ ) and epidermal growth factor (EGF) $(0.005-50 \mu \mathrm{g}$ $\left.\mathrm{I}^{-1}\right)$ on the number of cells and androstenedione and progesterone production were determined. Plating density had a marked effect on the pattern of hormone secretion with densities between 50 and $75 \times 10^{3}$ cells per well resulting in a high androstenedione:

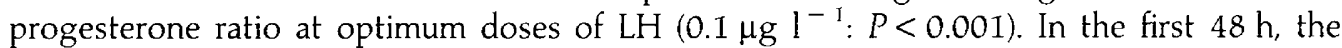
production of both androstenedione and progesterone was stimulated in a dose-dependent manner by LH $(P<0.001)$. However, the production of androstenedione was ten times higher than that of progesterone and was more sensitive to $L H\left(E_{50}\right.$ value $0.08 \mu \mathrm{g} \mathrm{l}^{-1}$ for androstenedione and $1 \mathrm{\mu g} \mathrm{l}^{-1}$ for progesterone). From 48-144 h of culture higher doses of $\mathrm{LH}$ ( $>1 \mathrm{ng} \mathrm{ml}^{-1}$ ) inhibited androstenedione $(P<0.001)$ and stimulated progesterone $(P<0.001)$ and resulted in a marked change in cell morphology, thus reflecting both functional and morphological luteinization. At optimum doses of LH, both insulin and IGF stimulated cell proliferation $(P<0.001)$ and androstenedione production $(P<0.001)$ in a dose responsive manner and there was a significant $(P<0.001)$ interaction between them. In contrast, both insulin and IGF-I inhibited $(P<0.001)$ progesterone production in a dose responsive manner. EGF stimulated cell proliferation $(P<0.001)$ and progesterone production $(P<0.001)$, but inhibited androstenedione production $(P<0.001)$, in a dose responsive manner. In conclusion, this culture system exhibits physiologically relevant responses to known in vivo modulators of follicle development. The biphasic nature of the theca cell response to $\mathrm{LH}$ emphasises the exquisite sensitivity of theca cells to $\mathrm{LH}$ stimulation and highlights the importance of dose-response relationships in the gonadotrophic control of ovarian function.

\section{Introduction}

The vascular theca cell layer forms from mesenchymal cells in early pre-antral follicles, and under the influence of endocrine, autocrine and paracrine factors some cells differentiate into steroidogenic theca-interstitial cells (for review see Erickson et al., 1985). In preantral follicles these cells are capable of producing progesterone in response to LH (Erickson et al, 1985) but at the time of antrum formation they differentiate further, expressing P-450 17a-hydroxylase (P-450 ${ }_{17 u}$ : Erickson et al., 1985; Xu et al., 1995a) and thereby gain the ability to secrete androgens. As follicle development continues

*Department of Agriculture and Horticulture, University of Nottingham, Sutton Bonington Campus, Loughborough, Leics LE12 5RD. UK.

Received 12 June 1997
LH-stimulated androgen is either secreted into the peripheral circulation or crosses the basement membrane as a substrate for oestrogen synthesis by the granulosa cells of large antral follicles (Baird et al., 1977; Moor, 1977; Baird and McNeilly, 1981). After the pre-ovulatory LH surge, P-450 174 expression declines and $\mathrm{P}-450$ side chain cleavage $\left(\mathrm{P}-45 \mathrm{O}_{\mathrm{SCC}}\right)$ expression increases as the cells luteinize to form part of the corpus luteum (Voss and Fortune, 1993; Smith et al., 1994). In addition to these endocrine systems, thecal cell function in antral follicles is modulated by the action of a number of local autocrine and paracrine factors. The theca expresses insulin-like growth factor II (IGF-II), the IGF type 1 receptor (Perks et al., 1995) and several IGF-BPs (Besnard et al, 1996; Perks and Wathes, 1996) transforming growth factor $\alpha / E G F$ and their receptor (Skinner and Coffey, 1988; Wynn et al., 1988; Lobb and Dorrington, 
1992), TNF $\alpha$ (Terranova, 1997) and FGF (Vanwezel, 1995). In addition, theca cell function is regulated by paracrine mechanisms (Smyth et al., 1993) that may involve granulosa cell derived inhibin (Hillier et al., 1991a) or activin (Hillier et al., 1991b).

In large domestic ruminants, although molecular biological techniques have been used to elucidate the cellular localization and the expression of steroidogenic enzymes (Tian et al., 1995; $\mathrm{Xu}$ et al., 1995a), LH receptor ( $\mathrm{Xu}$ et al., 1995b) and cytokines (Lobb and Dorrington, 1992; Perks et al., 1995; Vanwezel et al., 1995; Besnard et al., 1996; Perks and Wathes, 1996; Terranova, 1997) at different stages of follicle development, research on the mechanisms controlling thecal cell differentiation has been hampered by the lack of physiological culture systems. To date, no totally serum-free culture systems for sheep or cattle theca cells have been reported and usually when serum (Wrathall and Knight, 1995; Spicer and Stewart, 1996) or serum replacements (Demeter-Arlotto et al., 1993) are used some degree of spontaneous luteinization occurs so that progesterone secretion is 20-1000 times that of androstenedione. Although it is difficult to determine the proportions of steroids secreted by theca-interstitial cells in vivo, the best estimates, derived from freshly isolated bovine theca interna perifused in vitro, indicate that $97 \%$ of the steroids secreted are androgens (androstenedione $82 \%$ and testosterone $5 \%$ ) and only $1 \%$ is progesterone (McNatty et al., 1984). These proportions are in broad agreement with the results of studies in which ovarian steroid secretion from ovaries devoid of large oestrogenic follicles or luteal tissue has been determined (Campbell et al., 1991a, b).

The problem of spontaneous luteinization of theca cells in culture is not confined to ruminants. Engelhardt et al. (1991) reported low long-term viability of porcine theca cells cultured without serum and rapid spontaneous luteinization when serum was added. Similarly, human theca cells cultured in serum-free media lose the ability to secrete androgen after 3-4 days (Gilling-Smith et al., 1994) and cells cultured on serum-coated plates secrete considerable quantities of progesterone (Hillier et al., 1991a, b). A primary serum-free culture system for thecal cells in which androgen production can be induced with time has been reported in rats, but only when cells are isolated from hypophysectomized immature animals (for review see Erickson et al, 1985). When studying paracrine/autocrine mechanisms, the use of a serum-free culture system is particularly advantageous as the addition of serum can introduce a wide variety of poorly defined agents that can affect cell function.

We have recently reported the development of a primary serum-free culture system for ovine (Campbell et al., 1996) and bovine (Gutierrez et al., 1997a) granulosa cells in which the problem of spontaneous luteinization has been overcome. In the present study the same general principles have been applied in the development of a serum-free culture system for theca cells which allows the maintenance of LH-responsive androgen production by undifferentiated cells from small follicles. Furthermore, with this culture system, the ability of theca cells to secrete androgen or progesterone can be differentially regulated by the dose or time of exposure to LH. This culture system was used to study the proliferative and steroidogenic effects of insulin, IGF-I and EGF on cells from small follicles.

\section{Materials and Methods}

\section{Materials}

The following items were purchased from the Sigma Chemical Co. Ltd (Poole, Dorset): Dulbecco's minimum essential medium: Ham's F12 media (1:1; DMEM:F12) with $15 \mathrm{mmol}$ HEPES $1^{-1}$ and sodium bicarbonate; Penstrep containing $10000 \mathrm{IU}$ Penicillin and $10 \mathrm{mg}$ Streptomycin $\mathrm{I}^{-\mathrm{I}}$, BSA, tissue culture grade; transferrin, selenium; bovine insulin; neutral red; trypsin; oestradiol, collagenase, hyaluronidase, protease, deoxyribonuclease and Trypan blue. The following items were purchased from GIBCO BRL, Life Technologies Ltd, Paisley, Renfrewshire: Medium 199, 10 times concentrate; $1 \mathrm{~mol}$ HEPES, $\mathrm{I}^{-1} ; 250 \mu \mathrm{g}$ Amphotericin, $\mathrm{ml}^{-1} ; 200 \mathrm{mmol}$ L-glutamine, $\mathrm{l}^{-1}$; Dulbecco's phosphate-buffered saline without calcium or magnesium (DPBS ${ }^{-}$); Dulbecco's phosphatebuffered saline $\left(\mathrm{DPBS}^{+}\right.$); donor calf serum (DCS). Human recombinant IGF-I and Long R3 IGF-I (LR3-IGF-I; media grade) were purchased from Gropep Pty Ltd (Adelaide, SA). EGF was purchased from Toyoba Co. Ltd (Osaka). The remainder of the chemicals used were Analar grade and were obtained from general laboratory suppliers. Ovine luteinizing hormone (NIADDK-oLH-26; bioactivity $2.3 \mathrm{IU} \mathrm{mg}^{-1}$ with one unit being equal to the activity of $1 \mathrm{mg}$ of NIH-LH-SI as determined by the ovarian ascorbic acid depletion bioassay) was generously donated by the National Institute of Arthritis, Diabetes and Digestive and Kidney Diseases (Torrance, CA).

Sterile culture plates, bottles and dishes were obtained from Nunclon (Life Technologies, Paisley); sterile plastic syringes were obtained from Terumo Corp. (Terumo Europe, Leuven); sterile plastic univeral containers and centrifuge tubes and petri dishes were obtained from Greiner Labortechnik Ltd (Cam, Dursley, Glos) or Bibby Sterilin Ltd (Stone, Staffs).

\section{Isolation of theca cells}

Small (2.0-3.5 $\mathrm{mm}$ in diameter) ovarian follicles were isolated from ovaries collected from an abattoir, and granulosa cells and thecal shells were separated as described by Campbell et al. (1996). Briefly, coarse and fine dissection was carried out in Medium 199 containing $20 \mathrm{mmol}$ HEPES $\mathrm{l}^{-1}, 100 \mathrm{kIU}$ Penicillin $\mathrm{I}^{-1}, 0.1 \mu \mathrm{g}$ Streptomycin $\mathrm{1}^{-1}$ and $1 \mathrm{mg}$ Amphotericin (Fungizone) $1^{-1}$ at $37^{\circ} \mathrm{C}$ with specific attention being given to the removal of all extraneous stromal tissue from the follicle wall. Small follicles were hemisected in DPBS ${ }^{-}$and the follicle halves flushed repeatedly up and down the barrel of a $1 \mathrm{ml}$ syringe. The thecal shells were allowed to settle; the granulosa cell rich supernatant was removed; and the flushing procedure repeated.

The thecal shells were dispersed in an enzyme mix based on that described by Marcus et al. (1984). The thecal shells were

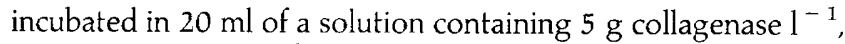
$1 \mathrm{~g}$ hyaluronidase $\mathrm{l}^{-1}, 1 \mathrm{~g}$ protease $\mathrm{l}^{-1}$ and $0.002 \% \mathrm{DCS}(\mathrm{v} / \mathrm{v})$ in DPBS $^{-}$at $37^{\circ} \mathrm{C}$ with gentle agitation. After incubation for $20 \mathrm{~min}, 200 \mu \mathrm{l}$ of $2 \mathrm{~g}$ deoxyribonuclease $1^{-1}$ in DPBS $^{-}$was added to the enzyme mix and the incubation continued until the theca were dispersed (normally 30-45 min). The reaction was then stopped by the addition of $2 \mathrm{ml}$ DCS and $10 \mathrm{ml}$ of the enzyme mix was added to $15 \mathrm{ml}$ centrifuge tubes 
containing $5 \mathrm{ml}$ culture medium (DMEM:F12 with $100 \mathrm{kIU}$ Penicillin $\mathrm{I}^{-1}, 0.1 \mu \mathrm{g}$ Streptomycin $\mathrm{I}^{-1}, 3 \mathrm{mmol}$ L-glutamine $\mathrm{I}^{-1}, 0.1 \% \mathrm{BSA}(\mathrm{w} / \mathrm{v}), 10^{-7} \mathrm{~mol}$ oestradiol $\mathrm{l}^{-1}, 2.5 \mathrm{mg}$ transferrin $\mathrm{I}^{-1}, 4 \mu \mathrm{g}$ selenium $\mathrm{l}^{-1}$ ) and centrifuged at $800 \mathrm{~g}$ for $10 \mathrm{~min}$. The cell pellets were then resuspended in culture medium and after a further wash the number and viability of cells were estimated using Trypan blue exclusion. Cell viability was routinely greater than $95 \%$.

\section{Theca cell cultures}

Twenty-five to one-hundred-thousand viable cells were seeded in a volume of $50 \mu \mathrm{l}$ into pre-prepared and equilibrated 96-well plates containing $200 \mu \mathrm{l}$ of culture medium with various concentrations and combinations of either insulin (1-5000 $\mathrm{ng} \mathrm{ml}^{-1}$ ), LR3-IGF-I (IGF-I; 1-100 $\mathrm{ng} \mathrm{ml}^{-1}$ ), LH (0.01-100 $\mathrm{ng} \mathrm{ml}^{-1}$ ) and EGF $\left(0.005-50 \mathrm{ng} \mathrm{ml}^{-1}\right)$ replicated in quadruplicate. Cells were cultured in a humidified atmosphere with $5 \% \mathrm{CO}_{2}$ in air at $37^{\circ} \mathrm{C}$. Cells were cultured for a total of 6 days and medium was changed at intervals of $48 \mathrm{~h}$. Disturbance of the cells was minimized by gently removing and replacing only $175 \mu \mathrm{l}$ of media at each change. The spent medium was stored at $-20^{\circ} \mathrm{C}$ before assay.

\section{Estimation of number of theca cells}

The number of viable cells per well after 6 days of culture was estimated using the neutral red method as described by Campbell et al. (1996). Briefly, at the end of the culture period, cells were incubated for $3 \mathrm{~h}$ at $37^{\circ} \mathrm{C}$ in a solution containing $10 \mu \mathrm{g}$ of the vital dye, neutral red. After fixation (with $4 \%$ $(\mathrm{w} / \mathrm{v})$ formaldehyde and $1 \%(\mathrm{w} / \mathrm{v})$ calcium chloride for $2-3 \mathrm{~min})$ the colour was developed by addition of $200 \mu \mathrm{l}$ of $50 \%(\mathrm{v} / \mathrm{v})$ ethanol and $1 \%(\mathrm{v} / \mathrm{v})$ glacial acetic acid and the absorbance determined at $540 \mathrm{~nm}$ using a multi-well plate reader. Absorbances were converted to number of cells using a standard curve generated from cells cultured separately in large numbers under similar conditions. The limit of detection of the assay was 2000 cells per well and the coefficients of variation were less than $5 \%$.

\section{Assays}

Concentrations of androstenedione and progesterone in unextracted culture media were determined using previously described radioimmunoassays (Campbell et al., 1990a) with the exception that progesterone antiserum SAPU R7044X (Scottish Antibody Production Unit) was used at an initial dilution of 1:10000. This antiserum has the following major crossreactions: $17 \alpha$-hydroxyprogesterone $2 \%, 5 \alpha$-pregnenalone $13 \%$, dihydrocorticosterone $4 \%$, $11 \beta$-hydroxyprogesterone $67 \%$, 11 $\alpha$-hydroxyprogesterone $76 \%$, corticosterone $1.6 \%$, androstenedione, oestradiol, oestrone, dihydrocorticosterone $<1 \%$. The sensitivity of the assays for androstenedione and progesterone were $18 \mathrm{pg}$ per tube and $50 \mathrm{pg}$ per tube, respectively. The intra- and inter-assay coefficients of variation for both androstenedione and progesterone were less than 15\%.

\section{Statistical analyses}

All hormone production data were expressed as ng of hormone produced by 10000 cells in $48 \mathrm{~h}$ after correction for the residual amount of media left in the wells when the media was changed at $48 \mathrm{~h}$ and $96 \mathrm{~h}$. Each experiment was repeated at least three times and the significance of treatment effects was determined by analysis of variance on $\log _{10}$ transformed data using replicate cultures as blocks. Individual comparisons between treatments were made using Bonferroni t-test.

\section{Results}

\section{Effect of plating density}

The effect of plating density $\left(25,50,75\right.$ or $100 \times 10^{3}$ cells per well) and dose of $\mathrm{LH}\left(0,0.1\right.$ and $\left.1 \mu \mathrm{g} \mathrm{LH} \mathrm{l}^{-1}\right)$ on the number of cells and steroid production after $144 \mathrm{~h}$ of culture are shown (Fig. 1). These cultures were performed either in the presence of $5 \mathrm{mg}$ insulin $\mathrm{l}^{-1}$ (thus making the formulation identical to the insulin, transferrin, selenium or ITS supplement commonly used for serum-free culture) or in the presence of $10 \mu \mathrm{g}$ IGF-I $\mathrm{l}^{-1}$ and $10 \mu \mathrm{g}$ insulin $\mathrm{l}^{-1}$ (10/10: the optimal mix for ovine granulosa cells). Results for the 10/10 treatment only will be presented as, although the trends were similar for both treatments, ITS resulted in lower $(P<0.001)$ androgen to progesterone ratios.

Over the 6 days of culture, regardless of the initial plating density, the number of cells increased $(P<0.001)$ by $20-30 \%$ in the absence of or presence of the low dose LH (Fig. Ia). In contrast, the number of cells did not change with time when the cells were exposed to the highest dose of LH (Fig. 1a). When corrected for the number of cells, both plating density $(P<0.001)$ and dose of $\mathrm{LH}(P<0.001)$ had a marked effect on both androstenedione and progesterone production and there were significant interactions $(P<0.05)$ between these two main effects (Fig. 1 b , c). Both doses of LH stimulated androstenedione production $(P<0.001)$ and, although increasing plating density resulted in a decrease in androstenedione production, this effect was much more marked for the high dose of LH (Fig. Ib). In contrast, only the highest dose of LH stimulated progesterone production $(P<0.001)$ and the inhibitory effect of plating density was more marked at lower doses of LH (Fig. Ic). These differential effects resulted in a striking effect of plating density and LH on the androgen to progesterone ratio (A4:P4; Fig. Id) such that cells plated at densities between $50-75 \times 10^{3}$ cells per well and cultured in the presence of low doses of LH primarily secreted androstenedione (A4:P4 $>10$ ), whereas under other conditions the cells secreted more progesterone than androstenedione (A4:P4 $\leqslant 1$ ).

\section{Responses to $\mathrm{LH}$ with time}

The number of cells and morphological responses to $L H$. In the absence of, or at low doses of, LH the theca cells assumed a flattened fibroblastic appearance and grew as a dispersed monolayer (Fig. 2a). Increasing doses of $\mathrm{LH}$ resulted in a progressive change in cell morphology as the cells aggregated to form dense clumps with very elongated cells anchoring these clumps to the cell surface (Fig. 2b). Despite these morphological changes, LH had little effect on the number of cells after 6 days of culture: the only effect was an increase 
(a)

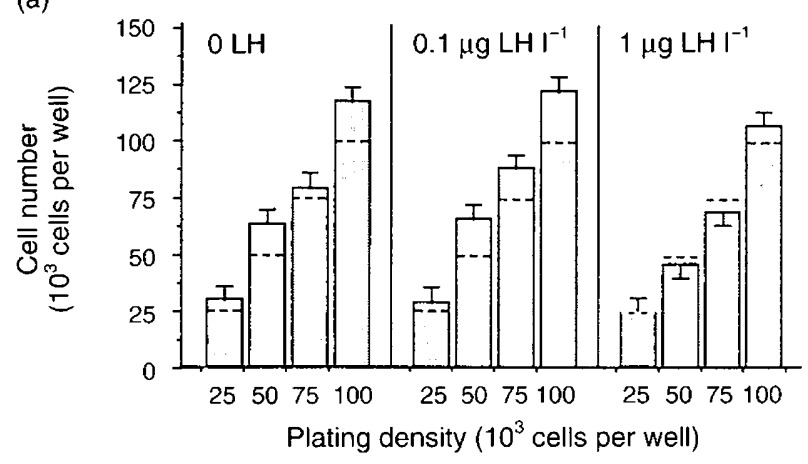

(b)

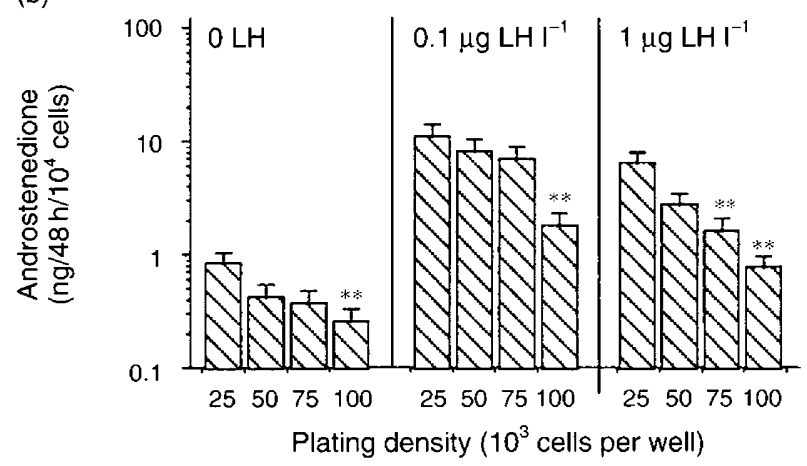

(c)

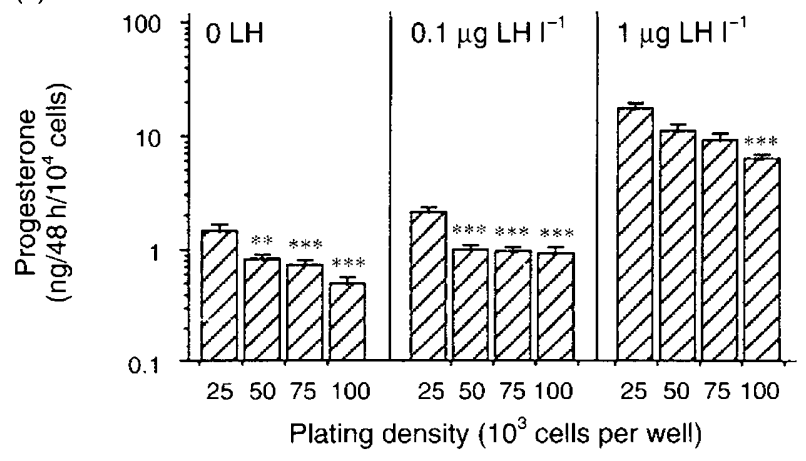

(d)

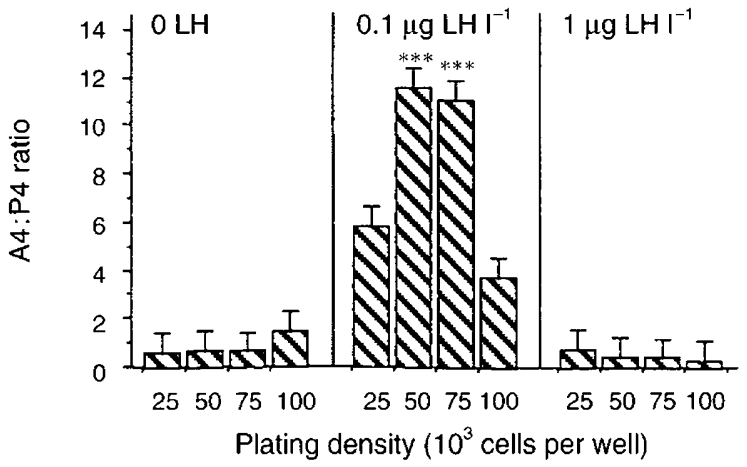

Fig. 1. The effect of plating density and dose of LH on (a) number of cells (dashed line indicates number of cells plated), (b) androstenedione (A4) production and (c) progesterone (P4) production and (d) A4:P4 ratio by theca cells cultured in the presence of $10 \mathrm{ng}$ insulin $\mathrm{ml}^{-1}$ and LR3-IGF-I $(10 / 10)$ after $144 \mathrm{~h}$ of culture. ${ }^{*} P<0.05,{ }^{* *} P<0.01$, $* * * P<0.001$ compared with plating density of $25 \times 10^{3}$ cells within each dose of $\mathrm{LH}$. Values are least squares means \pm SEM of three independent replicate cultures (ANOVA with Bonferroni).
$(P<0.01)$ in the number of cells at the lowest doses of LH $\left(0.001 \mu \mathrm{g} \mathrm{I}^{-1}\right.$ : Fig. 3). This increase was observed in the presence of either ITS or 10/10 although ITS stimulated cell division more $(P<0.001)$ than $10 / 10$ in the absence of, or at lower doses of, LH (Fig. 3).

Hormonal responses to $L H$. The effect of dose of LH on thecal androstenedione and progesterone production with time in culture is shown (Fig. 4). Results are presented for 10/10 only because, although the responses were very similar, ITS resulted in lower androstenedione $(P<0.001)$ and unchanged progesterone production. In the first $48 \mathrm{~h}$ of culture (Fig. $4 \mathrm{a}$ ), although both androstenedione $(P<0.001)$ and progesterone $(P<0.001)$ production was stimulated in a dose-dependent manner by $\mathrm{LH}$, the maximum effective dose $\left(E D_{\text {max }}\right)$ and $E_{50}$ values were 10 -fold lower for androstenedione $\left(E D_{\max }\right.$ value $0.5 \mu \mathrm{g} \mathrm{l}^{-1} ; \mathrm{ED}_{50}$ value $0.08 \mu \mathrm{g} \mathrm{l}^{-1}$ ) than for progesterone $\left(\mathrm{ED}_{\max }\right.$ value $5 \mu \mathrm{g} \mathrm{l}^{-1} ; \mathrm{ED}_{50}$ value $1 \mu \mathrm{g} \mathrm{l}^{-\mathrm{I}}$ ). From $48-144 \mathrm{~h}$ of culture, although androstenedione production was maintained at lower doses of LH (Fig. 4b, c), at higher doses of LH $\left(>1 \mathrm{ng} \mathrm{ml}{ }^{-1}\right.$ ) androstenedione production was inhibited $(P<0.001)$ and progesterone production was stimulated $(P<0.001)$. Thus the androstenedione response curve became biphasic with an $\mathrm{ED}_{\max }$ value of $0.1 \mu \mathrm{g} \mathrm{l}^{-1}$ and an $\mathrm{ED}_{50}$ value of $0.01 \mu \mathrm{g} \mathrm{l}^{-1}$. In contrast, the progesterone dose-response curve remained sigmoidal with a progressive shift $(P<0.01)$ in the maximum progesterone production (Fig. 4), $\mathrm{ED}_{\max }$ value (5 and $0.5 \mu \mathrm{g} \mathrm{l}^{-1}$ for 96 and $144 \mathrm{~h}$, respectively) and $\mathrm{ED}_{50}$ value ( 0.5 and $0.2 \mu \mathrm{g} \mathrm{l}^{-1}$ for 96 and $144 \mathrm{~h}$, respectively).

\section{Interaction between insulin and IGF-I in the presence of $L H$}

Cell proliferation. After culture for 6 days under serum-free conditions in the presence of a low dose of $\operatorname{LH}\left(0.1 \mu \mathrm{g} \mathrm{l}^{-1}\right)$ but in the absence of either insulin or IGF, the number of theca cells was maintained at the plating density (Fig. 5). In the absence of IGF-I, insulin increased the number of cells in a dose responsive manner $(P<0.001)$. There was a significant $(P<0.001)$ interaction between insulin and IGF-I with the addition of increasing doses of IGF-I resulting in a flattening of the proliferative dose-response curve to insulin so that at doses greater than

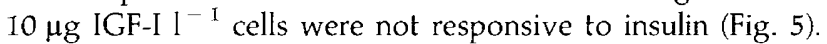

Androstenedione production. Insulin alone, in the presence of low LH, stimulated androstenedione production in a dose responsive manner $(P<0.001)$ with the supraphysiological dose of $1 \mathrm{mg} \mathrm{l}^{-1}$ resulting in maximal production. As with the number of cells, there was a significant $(P<0.001)$ interaction between insulin and IGF-I with the addition of increasing doses of IGF-I resulting in a flattening of the steroidogenic dose

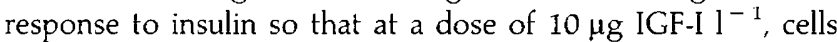
were not dose responsive to insulin. Increasing the dose of IGF-I from 10 to $100 \mu \mathrm{g} \mathrm{I}^{-1}$ resulted in a small but significant $(P<0.001)$ further increase in androstenedione production.

Progesterone production. In contrast to androstenedione, insulin inhibited progesterone production in a dose responsive manner $(P<0.001)$ with the supraphysiological dose of $5 \mathrm{mg}$ $\mathrm{I}^{-1}$ resulting in maximal suppression. There was a significant 

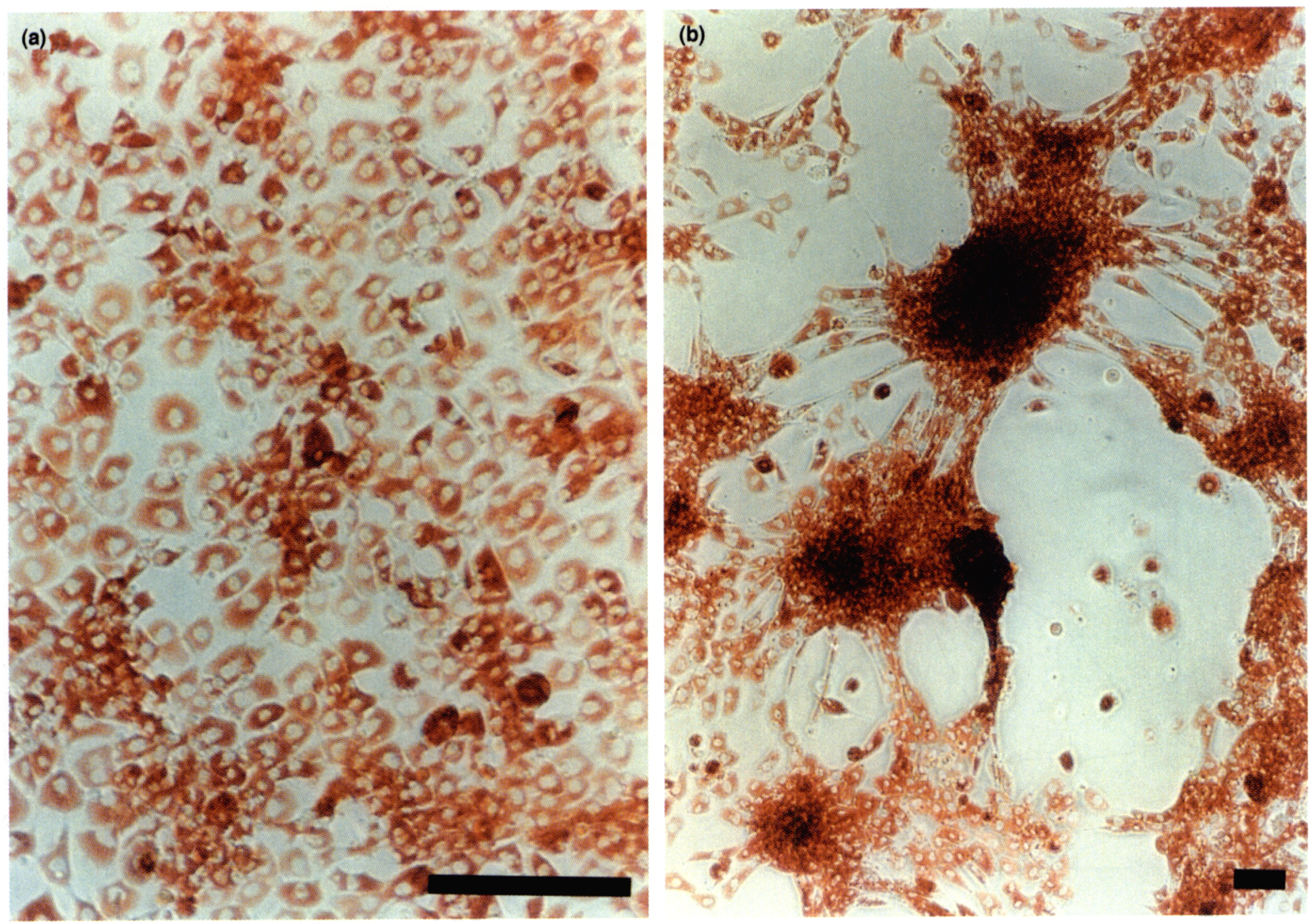

Fig. 2. Appearance of ovine theca cells cultured under serum-free conditions for $144 \mathrm{~h}$ in (a) the absence of $\mathrm{LH}$ and (b) $100 \mathrm{ng} \mathrm{LH} \mathrm{ml}^{-1}$. Scale bar represents $100 \mu \mathrm{m}$.

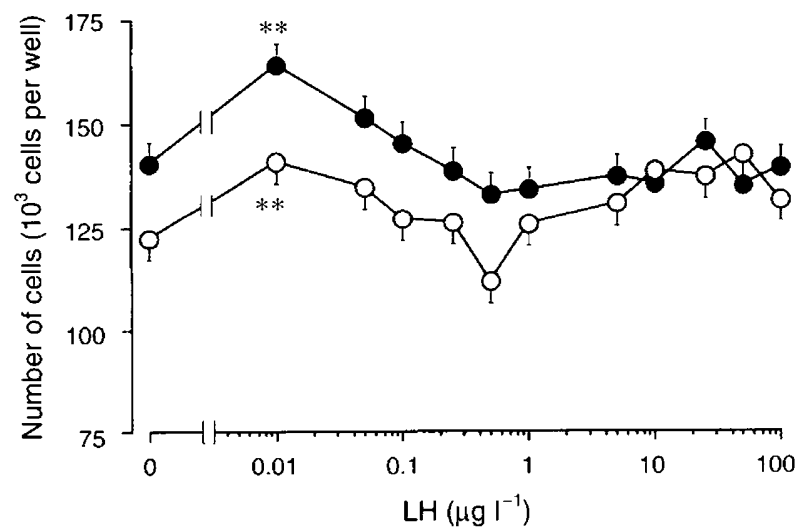

Fig. 3. The effect of LH on number of ovine theca cells after $144 \mathrm{~h}$ of culture in the presence of either $5 \mathrm{mg}$ insulin $\mathrm{I}^{-1}(\mathbf{O})$ or a combination $10 \mu \mathrm{g}$ of the IGF-I analogue Long R3 IGF-I and $10 \mu \mathrm{g}$ insulin $1^{-1}(O){ }^{* *} P<0.01$ compared with absence of $\mathrm{LH}$. Values are least squares means \pm SEM of three independent replicate cultures (ANOVA with Bonferroni).

$(P<0.001)$ interaction between insulin and IGF-I with doses of 1 and $10 \mu \mathrm{g}$ IGF-I ${ }^{-1}$ resulting in a progressive flattening of the steroidogenic dose response to insulin. IGF-I at
$100 \mu \mathrm{g} \mathrm{I}^{-1}$, however, resulted in a marked increase $(P<0.001)$ in progesterone production to values similar to those observed for cells cultured in the absence of insulin or IGF-I.

\section{Effect of epidermal growth factor}

EGF, in the presence of $\mathrm{LH}\left(0.1 \mathrm{gg} \mathrm{l}^{-1}\right)$ and $10 / 10 \mathrm{insulin} /$ IGF-I, stimulated a dose responsive increase in the proliferation of theca cells $(P<0.001)$ but had no marked effect on the morphology of the cultured cells. When corrected for the number of cells, EGF had inverse effects on steroid production, inhibiting androstenedione $(P<0.001)$ and stimulating progesterone $(P<0.001)$ production with an $\mathrm{ED}_{50}$ value for both steroids of about $0.1 \mu \mathrm{g}^{-1}$ (Fig. 6).

\section{Discussion}

This study describes, for the first time, a serum-free ovine theca cell culture system that overcomes the problem of spontaneous luteinization so that cells maintain the ability to secrete predominantly androstenedione in response to physiological doses of LH. Furthermore, the ability of theca cells to secrete androgen or progesterone was shown to be influenced by the 

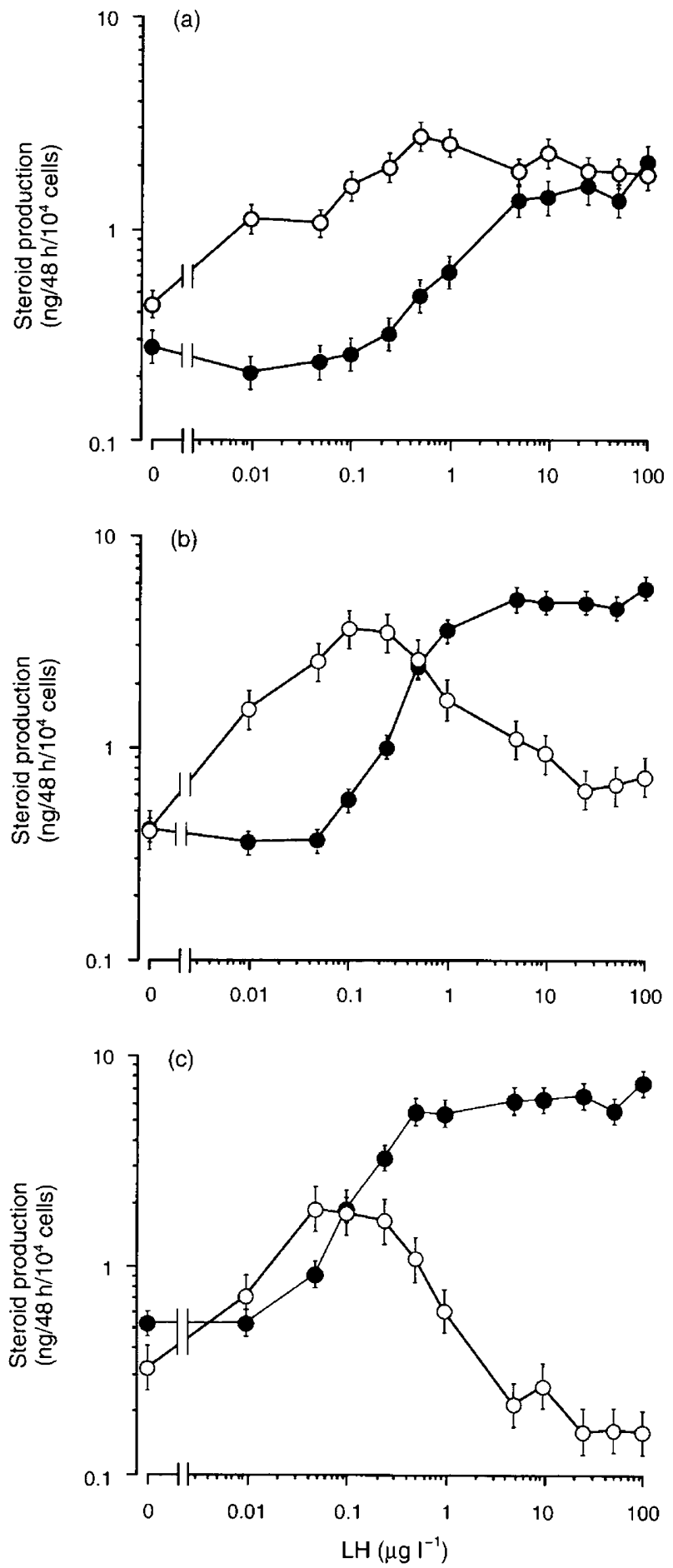

Fig. 4. The production of androstenedione $(O)$ and progesterone $(0)$ by ovine theca cells in response to LH after (a) 48 , (b) 96 and (c) $144 \mathrm{~h}$ of culture. $10^{5}$ cells per well were plated and the cultures were performed in the presence of $10 \mu \mathrm{g}$ of the IGF-I analogue Long R3 IGF-I and $10 \mu \mathrm{g}$ insulin $!^{-1}$. Values are least squares means \pm SEM of three independent replicate cultures (ANOVA with Bonferroni).

dose and time of exposure to $\mathrm{LH}$, therefore reflecting both morphological and functional luteinization. Finally, the ability of LH to stimulate thecal androgen production was shown to be modulated by both proliferative growth factors and
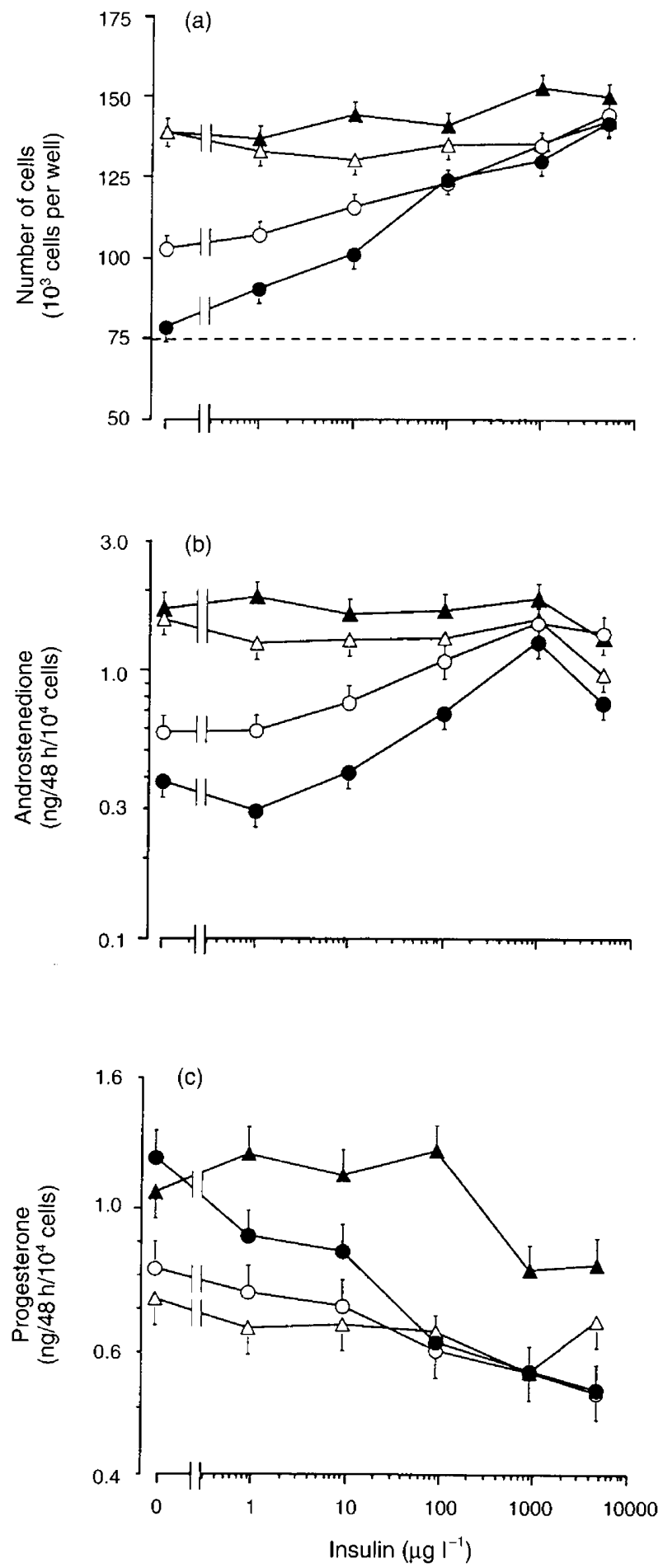

Fig. 5. The effect of insulin on (a) number of cells, (b) androstenedione production and (c) progesterone production by ovine theca cells isolated from small $(<3.5 \mathrm{~mm})$ follicles after 6 days of culture under serum-free conditions in combination with $0(\Theta), 1(O), 10(\triangle)$ or $100(\mathbf{\Delta}) \mu \mathrm{g}$ of the IGF-I analogue Long R3 IGF-I ${ }^{-1}$. All cultures were performed in the presence of $0.1 \mu \mathrm{g}$ oLH-26 $\mathrm{l}^{-1}$. The dotted horizontal line indicates the number of cells plated at the start of culture. Note that the androstenedione and progesterone data have been corrected for the effect of number of cells. Values are least squares means \pm SEM of three independent replicate cultures (ANOVA with Bonferroni). 


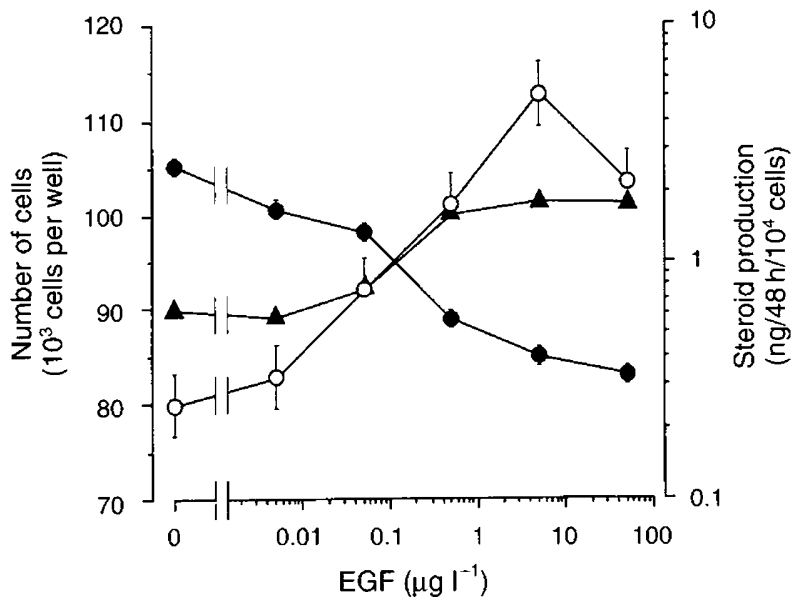

Fig. 6. The effect of epidermal growth factor (EGF) on number of cells $(O)$ and androstenedione $(\boldsymbol{O})$ and progesterone $(\boldsymbol{\Delta})$ production by ovine theca cells isolated from small $(<3.5)$ follicles after 6 days of culture under serum-free conditions in the presence of $10 \mu \mathrm{g}$ IGF-I analogue Long R3 IGF-I and $10 \mu \mathrm{g}$ insulin $1^{-1}$ plus $0.1 \mu \mathrm{g}$ oLH-26 $1^{-1} .75 \times 10^{3}$ cells per well were initially plated. Note that the steroid data have been corrected for the effect of number of cells. Values are least squares means \pm SEM of three independent replicate cultures (ANOVA with Bonferroni).

components of the insulin-IGF system. In vivo, androstenedione is the major steroid secreted by the theca cells of large antral follicles in the ovarian vein and provides precursor for synthesis of oestrogens by the granulosa cell. After exposure to high concentrations of $\mathrm{LH}$ during the pre-ovulatory $\mathrm{LH}$ surge, androgen secretion is inhibited and progesterone is the major steroid produced by the theca-lutein cells of the corpus luteum. Thus the pattern of steroids produced by the theca cells in vitro in the present study is similar to that reported in vivo and gives some reassurance that the culture system reflects the events that occur in vivo.

The development of this culture system was based on the three basic features previously investigated in the development of a serum-free system for sheep granulosa cells (Campbell et al., 1996). The first is the use of a totally serum-free and attachment factor-free culture system. As with granulosa cells, although thecal cell viability is greatly improved when cultures are performed with preincubations in the presence of serum (Wrathall and Knight, 1995; Spicer and Stewart, 1996) or in the presence of serum replacements (Demeter-Arlotto et al., 1993), A4:P4 ratios decrease markedly under these conditions and superphysiological doses of $\mathrm{LH}$ are required to elicit significant steroidogenic responses (Demeter-Arlotto et al., 1993; Wrathall and Knight, 1995; Spicer and Stewart, 1996). The second key feature is the determination of optimum plating densities. As shown in this study, the steroidogenic products of the theca cells were highly dependent on the initial plating density and, even at optimum doses of $\mathrm{LH}$, the A4:P4 ratio fell if too few or too many cells were plated. It should be noted that nonoptimal plating densities, especially in the presence of high doses of LH, frequently lead to situations in which the theca cells secrete appreciable quantities of both androstenedione and progesterone in roughly equal amounts, indicating only partial luteinization of the theca cell population. Plating density also affects androgen production by cultured human thecal cells (Gilling-Smith et al., 1994).

The third key feature of the culture system is the inclusion of insulin or IGF-I. In contrast to granulosa cells, in which viability is poor in the absence of either of these factors, theca cell viability and steroidogenic capacity were high when the cells were maintained under insulin and IGF-I free conditions. However, such cells secreted mainly progesterone and both insulin and IGF-I resulted in a marked increase in the A4:P4 ratio. Although many of the effects of insulin at supraphysiological doses $\left(\geqslant 50\right.$ ug $\left.^{-1}\right)$ are probably mediated via crossreaction of insulin with the type I IGF receptor (Adashi et al., 1985), the results of this study show that IGF-I and insulin interact at doses in the physiological range to influence both cellular proliferation and hormone production. The LR3 IGF-I analogue used in these studies is ten times more potent than native IGF-I (B. K. Campbell unpublished), presumably because of its decreased affinity for IGF binding proteins, and as IGF-I concentrations in follicular fluid are in the region of $100 \mu \mathrm{g}^{-1}$ (Gong et al., 1996; Gutierrez et al., 1997b) the $10 \mu \mathrm{g} \mathrm{l}^{-1}$ dose can be regarded as the more physiological. It should be noted that superphysiological doses of both insulin $\left(5 \mathrm{mg} \mathrm{l}^{-1}\right)$ and LR3 IGF-I (100 ug $\mathrm{l}^{-1}$ ) resulted in maximal cell proliferation but were associated with lower A4:P4 ratios.

The most striking feature of the culture system described in this paper is the exquisite sensitivity of the theca cells to LH and the way the secretion of androstenedione or progesterone can be differentially regulated by the dose or time of exposure to LH. Although biphasic responses to gonadotrophins have been reported previously, such effects have been commonly observed at doses at the extremes of the physiological range (Berndtson et al., 1995). In sheep, basal circulating LH concentrations are less than $0.5 \mathrm{\mu g} \mathrm{l}^{-1}$ and pulse amplitudes range between 1 and $5 \mathrm{\mu g} \mathrm{l}^{-1}$ (Campbell et al., 1990b). The doses of $\mathrm{LH}$ to which androgenic responses were observed were therefore in the physiological range. However, the fact that continued exposure of theca cells to doses as low as $1 \mu \mathrm{g} \mathrm{l}^{-1}$ results in functional luteinization within $96 \mathrm{~h}$ emphasizes the physiological importance of the pulsatile mode of ovarian stimulation by LH. Indeed, the switch in thecal steroid production from androstenedione to progesterone in response to $\mathrm{LH}$ in vitro is very similar to the rapid fall in ovarian androgen secretion (Baird and McNeilly, 1981) and 17 $\alpha$-hydroxylase expression (Voss and Fortune, 1993) that occurs when circulating $\mathrm{LH}$ concentrations rise to values greater than $10 \mu \mathrm{g} \mathrm{l}^{-1}$ during the initiation of the preovulatory LH surge (Baird and McNeilly, 1981). The extreme sensitivity of the theca cell to LH stimulation helps to explain the well established observation that $\mathrm{LH}$ can inhibit FSH-stimulated follicle development (Chupin et al., 1987; Picton et al., 1990) but the mechanism of this effect is unclear. As the production of progesterone by cultured thecal cells reported here remains responsive to $\mathrm{LH}$ it is unlikely that the decline in thecal androgen secretion at higher doses of $\mathrm{LH}$ is due to downregulation of LH receptors. A more likely explanation is that higher doses of $\mathrm{LH}$ result in hyperstimulation of the adenylate cyclase pathway (Yong et al., 1994) or the activation of alternative signal transduction pathways, such as inositol triphosphate (Richards, 1994). It is unclear whether the differences in the shape of the androgenic LH dose-response curves after $48 \mathrm{~h}$ of 
culture (sigmoidal) and those at 96 and $144 \mathrm{~h}$ (biphasic) are due to differentiation of the thecal cells or are an artefact of the enzyme digestion, but studies are underway to examine these possibilities.

It has been suggested that paracrine factors that modulate the action of gonadotrophins on follicular cells are expressed at key points during folliculogenesis (Campbell et al., 1995). The recent observation that the fall in thecal $17 \alpha$-hydroxylase expression precedes that of $\mathrm{P}_{450}$ aromatase in the granulosa cells (Xu et al., 1995a) of declining dominant follicles in cattle, suggests that thecal cell function is a key determinant of follicular growth and development. The insulin-IGF system appears to one of the major intraovarian modulators of gonadotrophic action (Adashi et al., 1985; Campbell et al., 1995) and in sheep it has been shown that both insulin (Downing et al., 1993) and IGF-I (Campbell et al., 1993) can stimulate ovarian steroidogenesis in vivo and that both IGF-I and insulin interact at physiological concentrations to influence the cellular proliferation and hormone production of cultured granulosa cells (Campbell ef al., 1996). In the present study, these observations have been extended to show that both IGF-I and insulin stimulate the proliferation and androstenedione production of theca cells, but are generally inhibitory to progesterone production. Although there were significant interactions between insulin and IGF-I, responses to physiological concentrations of insulin $\left(\leqslant 10 \mathrm{ug} \mathrm{l}^{-1}\right)$ in the presence of IGF-I were small, indicating that IGF-I is likely to be a more potent intraovarian factor in vivo. Although it is clear that both granulosa and theca cells express IGF type I receptor in sheep (Perks et al., 1995), there is some controversy about whether follicular cells do (Leeuwenberg et al., 1995) or do not (Perks et al., 1995) express IGF-I in this species. However, whether locally produced or blood borne, the results of these studies suggest that IGF-I has a key role in modulating thecal differentiation.

In the study reported here, it was also demonstrated that EGF, in the presence of the 10/10 dose of insulin/IGF, stimulated thecal cell proliferation and progesterone production but inhibited LH-stimulated androstenedione synthesis. The inverse nature of the androstenedione and progesterone responses to EGF suggests that expression of $\mathrm{P}-450_{17 u^{\prime}}$ but not $\mathrm{P}-45 \mathrm{O}_{\mathrm{SCC}}$, may be directly responsive to EGF. These responses are consistent with results from studies involving intra-ovarian infusion of either EGF (Murray et al., 1992) or TGFa (Campbell et al., 1994). As the theca has been shown to express TGF $\alpha / E G F$ and their receptor (Skinner and Coffey, 1988; Wynn et al., 1988; Lobb and Dorrington, 1992), these observations also support the hypothesis that the stimulatory action of gonadotrophins can be modulated at the ovary by locally produced factors.

In conclusion, this study reports the development of a physiological culture system for sheep theca cells that allows both the maintenance of LH-responsive androgen production by cells from small follicles and the differential regulation of androstenedione and progesterone secretion by the dose and time of exposure to LH. Furthermore, use of this model system demonstrated that the stimulatory actions of LH can be modulated by physiological concentrations of insulin, IGF-I or EGF. The development of a physiologically relevant theca cell culture system for sheep provides a further valuable model for elucidating the complex endocrine, autocrine and paracrine mechanisms that control follicle development and selection in this species.

The authors gratefully acknowledge the technical assistance of G. Baxter, S Preen and L Harkness. This work was supported by the European Union (Project 00232, Contract AIR3-CT92-0232), Ministry of Agriculture and Fisheries (MAFF) and Office of Science and Technology (OST) and by MRC program grant G8929853.

\section{References}

Adashi EY, Resnick CE, D'ercole AJ, Svoboda ME and Van Wyk JJ (1985) Insulin-like growth factors as intraovarian regulators of granulosa cell growth and function Endocrine Reviews 6 400-420

Baird DT (1977) Evidence in vivo for the two-cell hypothesis of oestrogen synthesis by the sheep Graafian follicle Journal of Reproduction and Fertility $\mathbf{5 0}$ 183-185

Baird DT and McNeilly AS (1981) Gonadotrophic control of follicular development and function during the oestrous cycle of the ewe Journal of Reproduction and Fertility Supplement 30 119-133

Berndtson AK, Vincent SE and Fortune JE (1995) Low and high concentrations of gonadotropins differentially regulate hormone production by theca interna and granulosa cells from bovine preovulatory follicles Biology of Reproduction 52 1334-1342

Besnard N, Pisselet C, Monniaux D, Locatelli A, Benne F, Gasser F, Hatey F and Monget $\mathbf{P}$ (1996) Expression of messenger ribonucleic acids of insulin-like growth-factor binding protein-2, protein-4, and protein-5 in the ovine ovary - localization and changes during growth and atresia of antral follicles Biology of Reproduction 55 1356-1367

Campbell BK, Mann GE, McNeilly AS and Baird DT (1990a) The pattern of ovarian inhibin estradiol and androstenedione secretion during the estrous cycle in the ewe Endocrinology 127 227-235

Camphell BK, Mann GE, McNeilly AS and Baird DT (1990b) Pulsatile secretion of inhibin, oestradiol and androstenedione during the oestrous cycle of the ewe Journal of Endocrinology 126 385-393

Campbell BK, McNeilly AS, Mann GE and Baird DT (1991a) The effect of stage of estrous cycle and follicular maturation on ovarian inhibin production in sheep Biology of Reproduction 44 483-490

Campbell BK, Picton HM, Mann GM, McNeilly AS and Baird DT (1991b) The effect of steroid- and inhibin-free ovine follicular fluid on ovarian follicle populations and ovarian hormone secretion Journal of Reproduction and Fertility $93 \quad 81-96$

Campbell BK, Scaramuzzi RJ and Webb R (1993) IGF-I stimulates oestradiol production in sheep, both in vitro and in vivo. Journal of Reproduction and Fertility Abstact Series 12 Abstract 23

Campbell BK, Gordon BM and Scaramuzzi RJ (1994) The effect of ovarian arterial infusion of transforming growth factor $\alpha$ on ovarian hormone secretion by ewe with an autotransplanted ovary Journal of Endocrinology $143 \quad 13-24$

Campbell BK, Scaramuzzi RJ and Webb RW (1995) Control of antral follicle development and selection in sheep and cattle Journal of Reproduction and Fertility Supplement $49335-350$

Campbell BK, Scaramuzzi RJ and Webb R (1996) Induction and maintenance of oestradiol and immuno-reactive inhibin production with FSH by ovine granulosa cells cultured in serum free media Journal of Reproduction and Fertility 106 7-16

Chupin D, Cognie Y, Combarnous Y, Procureur R and Saumande J (1987) Effect of purified LH and FSH on ovulation in the cow and ewe. In Follicle Growth and Ovulation Rate in Farm Animals pp 63-72. Eds JF Roche and D O'Callaghan. Martinus Nijhoff, Dordrecht

Demeter-Arlotto M, Rainey WE and Simpson ER (1993) Maintenance and regulation of 17 alpha-hydroxylase expression by bovine thecal cells in primary culture Endocrinology $132 \quad 1353-1358$

Downing JA, Scaramuzzi RJ and Joss J (1993) The direct effect of insulin on ovarian steroid secretion in ewes with an ovarian autotransplant Proceedings of the Australion Society of Reproductive Biology Abstract 84

Engelhardt H, Gore-Langton RE, Armstrong DT (1991) Luteinization of porcine thecal cells in vitro. Molecular and Cellular Endocrinology 75 237-245

Erickson GF, Magoffin DA, Dyer CA and Hofeditz C (1985) The ovarian androgen producing cells: a review of structure/function relationships Endocrine Reviews 6 371-399 
Gilling-Smith C, Willis DS, Beard RW and Franks S (1994) Hypersecretion of androstenedione by isolated thecal cells from polycystic ovaries Journal of Clinical Endocrinology and Metabolism 79 1158-1165

Gong JG, Campbell BK, Bramley TA and Webb RW (1996) Treatment with recombinant bovine somatotrophin enhances ovarian follicle development and increases secretion of insulin-like growth factor-1 by ovarian follicles in ewes Animal Reproduction Science 41 13-26

Gutierrez CG, Campbell BK and Webb R (1997a) Development of a long-term bovine granulosa cell culture system: induction and maintenance of estradiol production, response to FSH and morphological characteristics Biology of Reproduction 56 608-616

Gutierrez CG, Campbell BK, Armstrong DG and Webb R (1997b) Insulin-like growth factor I (IGF-I) production by bovine granulosa cells in vitro and peripheral IGF-I measurements in cattle serum: an evaluation of IGFBP extraction protocols Journal of Endocrinology 153 231-240

Hillier SG, Yong EL, Illingworth PJ, Baird DT, Schwall RH and Mason AJ (1991a) Effect of recombinant inhibin on androgen synthesis in cultured human thecal cells Molecular and Cellular Endocrinology 75 R1-R6

Hillier SG, Yong EL, Illingworth PJ, Baird DT, Schwall RH and Mason AJ (1991b) Effect of recombinant activin on androgen synthesis in cultured human thecal cells Journal of Clinical Endocrinology and Metabolism 72 1206-1211

Leeuwenberg BR, Hurst PR, McNatty KP (1995) Expression of IGF-I messengerRNA in the ovine ovary Journal of Molecular Endocrinology 15 251-258

Lobb DK amd Dorrington J (1992) Intraovarian regulation of follicular development Animal Reproduction Science 28 343-354

McNatty KP, Heath DA, Lun S, Fannin JM, McDiarmid JM and Henderson KM (1984) Steroidogenesis by bovine theca interna in an in vitro perifusion system Biology of Reproduction 30 159-170

Marcus GJ, Conor L, Domingo MT, Tsang BK, Downey BR and Ainsworth L (1984) Enzymatic dissociation of ovarian and uterine tissues Endocrine Research 10 151-162

Moor RM (1977) Sites of steroid production in ovine Graafian follicles in culture Journal of Endocrinology 73 143-150

Murray JF, Downing JA, Evans G, Findlay JK and Scaramuzzi RJ (1992) Epidermal growth factor acts directly on the ovary in vivo to inhibit oestradiol-17 $\beta$ and inhibin secretion and enhance progesterone secretion Journal of Endocrinology $137253-264$

Perks CM and Wathes DC (1996) Expression of mRNAs for insulin-like growth factor binding proteins-2, -3 and -4 in the ovine ovary throughout the oestrous cycle Journal of Endocrinology $151241-249$

Perks CM, Denning Kendall PA, Gilmour RS and Wathes DC (1995) Localization of messenger ribonucleic acids for insulin-like growth-factor-I (IGF-I), IGF-II, and the type-I IGF receptor in the ovine ovary throughout the estrous-cycle Endocrinology 136 5266-5273

Picton HM, Tsonis CG and McNeilly AS (1990) The antagonistic effect of exogenous $\mathrm{LH}$ pulses on FSH-stimulated preovulatory follicle growth in ewes chronically treated with a gonadotrophin-releasing hormone agonist Journal of Endocrinology 127 273-283
Richards JS (1994) Hormonal control of gene expression in the ovary Endocrine Reviews 15 725-751

Skinner, M K and Coffey RJ, Jr (1988) Regulation of ovarian cell growth through the local production of transforming growth factor- $\alpha$ by theca cells Endocrinology 123 2632-2638

Smith MF, Mcintush EW, Smith GW (1994) Mechanisms associated with corpus-luteum development Journal of Animal Science 72 1857-1872

Smyth CD, Miro F, Whitelaw PF, Howles CM and Hillier SG (1993) Ovarian thecal interstitial androgen synthesis is enhanced by a follicle-stimulating hormone-stimulated paracrine mechanism Endocrinology 133 1532-1538

Spicer LJ and Stewart RE (1996) Interactions among basic fibroblast growth factor, epidermal growth factor, insulin, and insulin-like growth factor-I (IGF-I) on cell numbers and steroidogenesis of bovine thecal cells: role of IGF-I receptors Biology of Reproduction 54 225-263.

Terranova PF (1997) Potential roles of tumor necrosis factor-alpha in follicular development, ovulation, and the life span of the corpus luteum Domestic Animal Endocrinology 14 I-I5

Tian XC, Berndtson AK and Fortune JE (1995) Differentiation of bovine preovulatory follicles during the follicular phase is associated with increases in messenger-ribonucleic-acid for cytochrome-p450 side-chain cleavage, 3-beta-hydroxysteroid dehydrogenase, and p450 17-alpha-hydroxylase, but not p450 aromatase Endocrinology $1365102-5110$

Vanwezel IL, Umapathysivam K, Tilley WD, Rodgers RJ (1995) Immunohistochemical localization of basic fibroblast growth-factor in bovine ovarian follicles Molecular and Cellular Endocrinology 115 133-140

Voss AK and Fortune JE (1993) Levels of messenger-ribonucleic-acid for cytochrome-p450 17-alpha-hydroxylase and $\mathrm{p} 450$ aromatase in preovulatory bovine follicles decrease after the luteinizing-hormone surge Endocrinology $132 \quad 2239-2245$

Wrathall JHM and Knight PG (1995) Effects of inhibin-related peptides and oestradiol on androstenedione and progesterone secretion by bovine theca cells Journal of Endocrinology 145 491-500

Wynn PC, Avenell JR, Turnbull KE and Scaramuzzi RJ (1988) Localization of receptors for mouse epidermal growth factor (mEGF) in the sheep ovary Proceedings of the 8th International Congress of Endocrinology (Kyoto) 449

$\mathrm{Xu}_{\mathrm{u}} \mathrm{Z}$, Garverick HA, Smith GW, Smith MF, Hamilton SA and Youngquist RS (1995a) Expression of messenger RNA encoding cytochrome $P_{450}$ side chain cleavage cytochrome $\mathrm{P}_{450} 17$ a-hydroxylase and cytochrome $\mathrm{P}_{450}$ aromatase in bovine follicles during the first follicular wave Endocrinology $136981-989$

$\mathrm{Xu}$ ZZ, Garverick HA, Smith GW, Smith MF, Hamilton SA and Youngquist RS (1995b) Expression of follicle-stimulating-hormone and luteinizing-hormone receptor messenger ribonucleic acids in bovine follicles during the first follicular wave Biology of Reproduction 53 951-957

Yong EL, Hillier SG, Turner M, Baird DT, Ng SC, Bongso A and Ratnam SS (1994) Differential regulation of cholesterol side-chain cleavage ( $\mathrm{p} 450 \mathrm{scc}$ ) and aromatase (p450arom) enzyme messenger-RNA expression by gonadotropins and cyclic-AMP in human granulosa-cells journal of Molecular Endocrinology 12 239-249 